\title{
Decomposition Characteristics, Nutrient Release, and Structural Changes of Maize Straw in Dryland Farming under Combined Application of Animal Manure
}

\author{
Ling Sun ${ }^{1}$, Zhixu Sun ${ }^{2}$, Juan $\mathrm{Hu}^{3}$, Opoku-Kwanowaa Yaa ${ }^{1}$ and Jinggui $\mathrm{Wu}^{1, *}$ \\ 1 College of Resource and Environmental Science, Jilin Agricultural University, Changchun 130118, China; \\ sunling223@126.com (L.S.); yokwanowaa@gmail.com (O.-K.Y.) \\ 2 Jilin Province Soil Fertilizer Station, Changchun 130033, China; sunzhixu2007@126.com \\ 3 Jilin Provincial Laboratory of Grassland Farming, Northeast Institute of Geography and Agroecology Chinese \\ Academy of Sciences, Changchun 130102, China; hujuan@iga.ac.cn \\ * Correspondence: wujinggui@jlau.edu.cn
}

Citation: Sun, L.; Sun, Z.; Hu, J.; Yaa, O.-K.; Wu, J. Decomposition Characteristics, Nutrient Release, and Structural Changes of Maize Straw in Dryland Farming under Combined Application of Animal Manure. Sustainability 2021, 13, 7609. https:// doi.org/10.3390/su13147609

Academic Editor: Changhyun Roh

Received: 27 May 2021

Accepted: 5 July 2021

Published: 7 July 2021

Publisher's Note: MDPI stays neutral with regard to jurisdictional claims in published maps and institutional affiliations.

Copyright: (c) 2021 by the authors. Licensee MDPI, Basel, Switzerland. This article is an open access article distributed under the terms and conditions of the Creative Commons Attribution (CC BY) license (https:// creativecommons.org/licenses/by/ $4.0 /)$.

\begin{abstract}
Straw and animal manure are major organic waste materials from agricultural ecosystems. Different kinds of animal manure combined with straw (AM-S) may have varying effects on the decomposition, nutrient release, and structural changes of maize straw. Using the Humic Cambisols soil as the experimental area, the straw decomposition characteristics under the co-application of animal manure were studied following the nylon net bag landfill method. The experiment involved four treatments: maize straw only (S), maize straw plus ox manure (SO), maize straw plus chicken manure (SC), and maize straw plus pig manure (SP). The treatments with AM-S accelerated the decomposition of straw and increased the release rate of nutrients and organic components (cellulose, hemicellulose, and lignin). During the 240 days of the study, straw decomposition showed a trend of increasing rapidly in the first stages and then increasing slowly in the latter stages in all the treatments. At $240 \mathrm{~d}$, the straw decomposition rates and carbon release rates of the AM-S treatments were $65.25-71.87 \%$ and $64.04-69.35 \%$, respectively. At the end of the experiment, the order for the final release rates of nitrogen $(\mathrm{N})$, phosphorus $(\mathrm{P})$, and potassium $(\mathrm{K})$ was $\mathrm{K}(93.25-96.56 \%)>\mathrm{P}(42.25-55.08 \%)>\mathrm{N}(40.01-52.23 \%)$. Moreover, scanning electron microscopy showed that SP treatment had the highest degree of structural changes of the maize straw compared with the other treatments. The purpose of this study was to screen the effective animal manure that can promote straw decomposition and provide a reference for the rational use of straw and animal manure management. In conclusion, the study suggested that the co-application of animal manure and straw should be adopted in agricultural systems, especially SP treatment, as it was more conducive to promoting the decomposition of maize straw and the release of nutrients.
\end{abstract}

Keywords: animal manure; maize straw; nutrient release; decomposition

\section{Introduction}

Straw and animal manure contain macro- and micronutrient elements necessary for plant growth; hence, returning them to the field is an important fertilization practice in agricultural systems [1-3]. Crop residues such as maize straw have a wide carbon to nitrogen $(\mathrm{C} / \mathrm{N})$ ratio and high cellulose content [4], hence often resulting in low nitrogen mineralization due to nitrogen immobilization in the soil. This poses a negative impact on the content of available nitrogen to plants in the soil and also slows the decomposition process [5]. On the other side, animal manure has a high nitrogen concentration and narrow $\mathrm{C} / \mathrm{N}$ ratio and hence usually leads to high $\mathrm{C}$ and $\mathrm{N}$ mineralization [6]. Das et al. [7] found that, comparatively, mixtures of straw and animal dung are more suitable for composting and improving soil properties other than the individual application of each component. Mary et al. [8] showed that adding fertilizer $\mathrm{N}$ to the soil might stimulate the 
nutrient release from returned straw and partially offset the immobilization process of straw decomposition.

A large number of studies have suggested measures to promote straw decomposition, mainly by focusing on different nitrogen application rates from the organic materials, different returning methods, and straw combined with an application of different fertilizers or decaying agents $[9,10]$. Zhao et al. [11] found that the return of straw along with different fertilizers increased the straw decomposition rate, which was attributed to the greater biomass and diversity of fungi and bacteria. Latifmanesh et al. [12] also reported the effects of straw incorporation depth on soil $\mathrm{C}$ and $\mathrm{N}$ release and the decomposition rate of maize straw in a wheat-maize cropping system. However, there are few studies on the effects of adding different animal manure on straw decomposition and nutrient release.

Animal manure is an important method of heating in some countries, especially in Asia. In Nepal, northwestern India, and Central Asia, animal manure is burnt for heating purposes [13]. Sometimes, the animal manure is mixed with grass manure for cooking and heating in the plains of the Everglades or the treeless Himalayas. In China, more than 4 billion tons of animal manure are produced annually, a small portion of which is used for arable land because of the high costs involved in manure transport, application, and treatment [14]. In winter and spring, the indigenous Tibetan combusting yak manure is also used for heating in some parts of China [15].

The objective of this study was to screen the effective animal fertilizer, which can promote straw decomposition and provide a reference for rational use of straw and animal fertilizer management. In this study, the nylon net bag method was used to explore the straw decomposition rate, nutrient release, chemical composition, and structural changes under the combined application of animal manure. This will help to select the most effective animal manure that can promote straw decomposition and also provide a theoretical basis for the rational and efficient utilization of straw and animal manure.

\section{Materials and Methods}

\subsection{Experimental Site}

Field experiments were conducted in Liaoyuan County, Jilin Province, Northeast China $\left(42^{\circ} 50^{\prime} 55^{\prime \prime} \mathrm{N}, 125^{\circ} 20^{\prime} 31^{\prime \prime} \mathrm{E}\right)$ (Figure 1). The climate of the experimental site is characterized by a temperate continental monsoon climate. The average annual temperature is $5.4{ }^{\circ} \mathrm{C}$, and the mean annual precipitation is $666.5 \mathrm{~mm}$. The frost-free period is approximately $140 \mathrm{~d}$, and the average yearly sun exposure is $2507 \mathrm{~h}$. The soil is classified as dark-brown soil, named Cryumbreps in the American soil classification system and Humic Cambisols in the World Reference Base for Soil Resources (WRB), with a pH of 6.3. The main basic properties of the soil were as follows: $12.34 \mathrm{~g} \mathrm{~kg}^{-1}$ total organic carbon, $1.25 \mathrm{~g} \mathrm{~kg}^{-1}$ total nitrogen, $100.44 \mathrm{mg} \mathrm{kg}^{-1}$ alkali-hydrolyzable nitrogen, $20.28 \mathrm{mg} \mathrm{kg}^{-1}$ available phosphorus, and $125.13 \mathrm{mg} \mathrm{kg}^{-1}$ available potassium. Artificial irrigation was not provided during the experiment.

\subsection{Field Experiment Design}

The field was arranged in a randomized block design consisting of four treatments in three replicates. Each plot had a dimension of $10 \times 5 \mathrm{~m}$, and the treatments were maize straw only (S), maize straw plus ox manure (SO), maize straw plus chicken manure (SC), and maize straw plus pig manure (SP). The chicken manure, ox manure, and pig manure were collected from chicken farms, ox farms, and pig farms in Liaoyuan County, and they were composted a few months before application. The basic properties of the organic materials used in this study are shown in Table 1.

In this experiment, the same amount of maize straw was applied to each plot (7300 $\mathrm{kg} \mathrm{ha}^{-1}$ ). The application of the animal manure was adjusted so that equal amounts of carbon (7738 kg C ha-1) can be applied in each plot in 2018 and 2019. The application rate for the animal manure was $32,500 \mathrm{~kg} \mathrm{ha}^{-1}$ for chicken manure, $25,123 \mathrm{~kg} \mathrm{ha}^{-1}$ for ox manure, and $24,333 \mathrm{~kg} \mathrm{ha}^{-1}$ for pig manure. In each plot, trenches were made whereby 
the same amount of maize straw was applied in all the treatment plots. Thus, pig manure, chicken manure, and cow manure were evenly spread on the maize straw for the respective treatment plots before sowing the maize. However, the focus of this study was to sample the litterbags for the experiment.

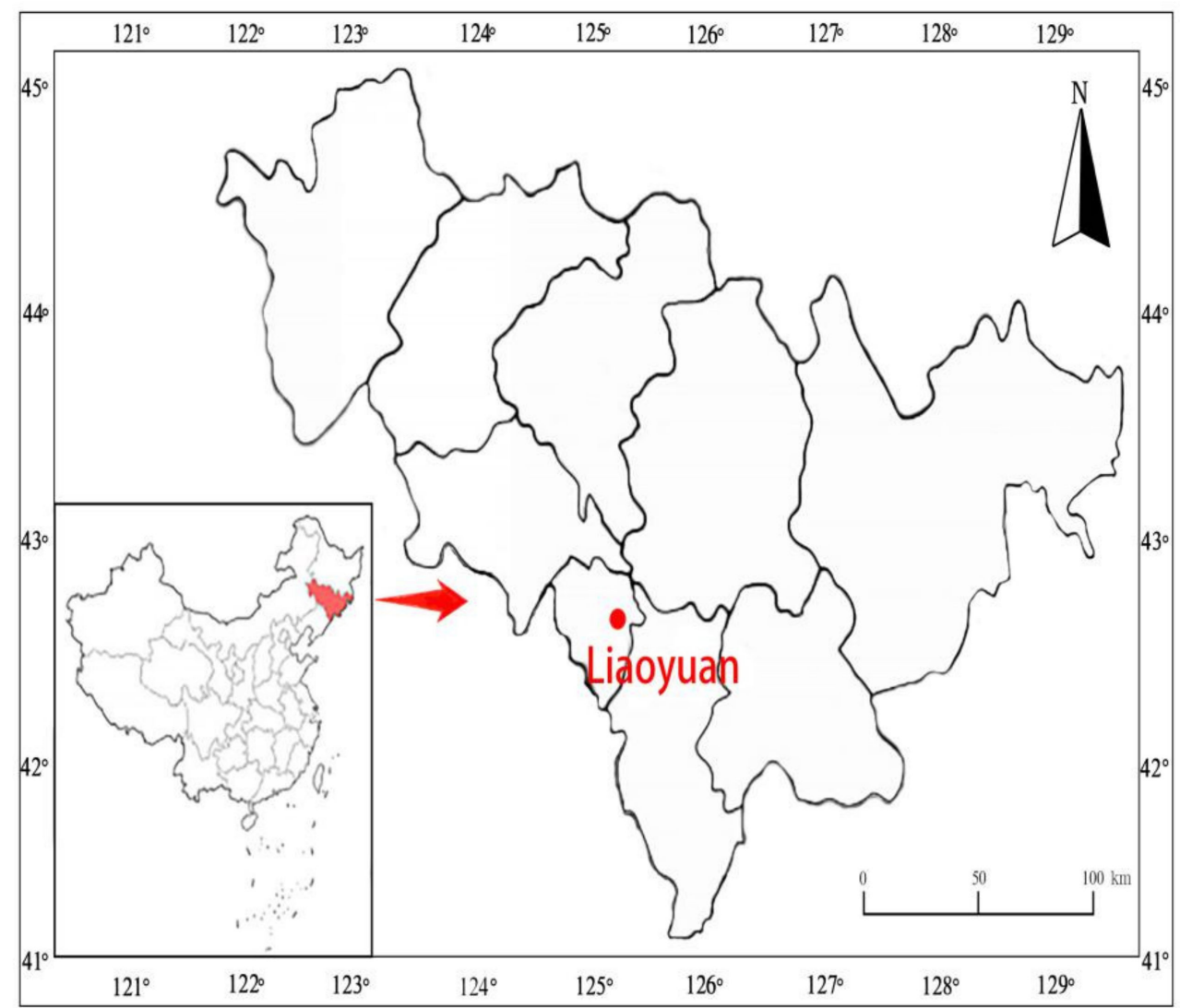

Figure 1. Location of the study area.

Table 1. Basic properties of the initial organic materials.

\begin{tabular}{ccccc}
\hline Property & Maize Straw & Ox Manure & Chicken Manure & Pig Manure \\
\hline Organic C (g/kg) & $423.05 \pm 1.93 \mathrm{a}$ & $308.15 \pm 2.10 \mathrm{c}$ & $238.61 \pm 3.09 \mathrm{~d}$ & $313.54 \pm 2.19 \mathrm{~b}$ \\
Total N $(\mathrm{g} / \mathrm{kg})$ & $6.52 \pm 0.46 \mathrm{~d}$ & $13.25 \pm 0.64 \mathrm{c}$ & $15.77 \pm 0.58 \mathrm{~b}$ & $17.2 \pm 1.01 \mathrm{a}$ \\
C/N & 65.11 & 23.29 & 15.14 & 18.27 \\
Total P (g/kg) & $1.20 \pm 0.06 \mathrm{~d}$ & $3.53 \pm 0.09 \mathrm{c}$ & $8.72 \pm 0.07 \mathrm{a}$ & $6.95 \pm 0.1 \mathrm{~b}$ \\
Total K (g/kg) & $12.31 \pm 0.09 \mathrm{~b}$ & $8.24 \pm 0.11 \mathrm{c}$ & $14.09 \pm 0.13 \mathrm{a}$ & $8.16 \pm 0.02 \mathrm{c}$ \\
Lignin (\%) & $6.32 \pm 0.2 \mathrm{~b}$ & $7.23 \pm 0.11 \mathrm{a}$ & $3.21 \pm 0.24 \mathrm{~d}$ & $5.09 \pm 0.31 \mathrm{c}$ \\
Cellulose (\%) & $32.28 \pm 0.64 \mathrm{a}$ & $23.53 \pm 1.4 \mathrm{~b}$ & $7.04 \pm 0.18 \mathrm{~d}$ & $14.41 \pm 0.24 \mathrm{c}$ \\
Hemicellulose (\%) & $22.37 \pm 1.1 \mathrm{a}$ & $15.38 \pm 0.46 \mathrm{~b}$ & $4.26 \pm 0.12 \mathrm{~d}$ & $13.24 \pm 0.3 \mathrm{c}$ \\
Polyphenol (\%) & $0.87 \pm 0.02 \mathrm{a}$ & $0.73 \pm 0.1 \mathrm{~b}$ & $0.68 \pm 0.06 \mathrm{~b}$ & $0.69 \pm 0.07 \mathrm{~b}$ \\
Lignin/N & $9.71 \pm 0.38 \mathrm{a}$ & $5.47 \pm 0.35 \mathrm{~b}$ & $2.04 \pm 0.21 \mathrm{~d}$ & $2.97 \pm 0.35 \mathrm{c}$ \\
Soluble substance $(\%)$ & $32 \pm 1.15 \mathrm{~d}$ & $42.24 \pm 0.51 \mathrm{~b}$ & $40.24 \pm 0.29 \mathrm{c}$ & $47.56 \pm 0.5 \mathrm{a}$ \\
\hline
\end{tabular}

Note: The different lowercase letters $(\mathrm{a}-\mathrm{d})$ among the different treatments indicate significance at $p<0.05$. Data with the same lowercase letter within the same row do not differ significantly at the $5 \%$ level. Mean \pm standard error. 
An in situ soil burying test of a nylon net bag was conducted in May 2018. In October 2017, the maize straw from the test area was collected as the initial straw materials and brought back to the laboratory for air drying. The crushing length of the stems and leaves was about $8 \mathrm{~cm}$, and the stalks and leaves were mixed evenly for use. Before straw bagging, $20.65 \mathrm{~g}$ of cow manure, $26.71 \mathrm{~g}$ of chicken manure, and $20 \mathrm{~g}$ of pig manure were used for $\mathrm{SO}, \mathrm{SC}$, and SP treatments (calculated according to the weight of straw in the straw bale, which was consistent with the application amount corresponding to the $7300 \mathrm{~kg} \mathrm{ha}^{-1}$ straw returned to the field in the field test). There were 96 sample bags ( 4 treatments $\times 3$ replicates $\times 8$ samples), and the dimensions for the sample bag were $15 \times 25 \mathrm{~cm}, 0.01 \mathrm{~mm}$ mesh size. The weight of straw in each bag was $6.00 \pm 0.03 \mathrm{~g}$, followed by adding the animal manure of each treatment, respectively, according to the equal carbon principle. The nylon bag was tied tightly and then buried in the corresponding plots of each treatment, respectively.

\subsection{Soil Sampling and Measurement}

Sample bags were destructively retrieved at 30, 60, 90, 120, 150, 180, 210, and 240 days after the bags were buried. At each sampling date 12 (4 treatments $\times 3$ replicates) nylon net bags were retrieved. On every sampling date, the litterbags were handled with great care during the removal process, and each litterbag was carefully transported in a separate plastic bag to minimize the loss of any small debris from the litterbag. The soil and root debris attached to the surface of the straw bag were washed with distilled water, followed by drying the straw bag at $65^{\circ} \mathrm{C}$ for analysis.

The dry weight of the straw was measured and weighed by a $1 \%$ balance. The organic carbon within the remaining straw was measured by the exogenous thermal process with potassium dichromate [16]. The total $\mathrm{N}$, total $\mathrm{P}$, and total $\mathrm{K}$ were measured following the Kjeldahl method, molybdenum antimony anticolorimetric method, and flame photometer, respectively. According to Equations (1) and (2), decomposition rate and nutrient release rate were calculated.

The decomposition rate of cellulose, hemicellulose, and lignin in straw: Van Soest acid detergent fiber [17] was used to determine their content and calculate the decomposition rate (Equation (3)).

The microstructure of the straw surface was observed by using a scanning electron microscope. After vacuum drying, the sample was sprayed with SEM gold spray, and the image was taken under $3 \mathrm{kV}$ acceleration voltage.

$$
\begin{gathered}
\text { Decomposition rate }(\%)=\left(\mathrm{M}_{0}-\mathrm{M}_{\mathrm{t}}\right) / \mathrm{M}_{0} \times 100 \% \\
\text { Nutrient release rate }(\%)=\left(\mathrm{M}_{0} \mathrm{C}_{0}-\mathrm{M}_{\mathrm{t}} \mathrm{C}_{\mathrm{t}}\right) / \mathrm{M}_{0} \mathrm{C}_{0} \times 100 \%
\end{gathered}
$$

Decomposition rate of straw organic components (cellulose, hemicellulose, and lignin) $(\%)=\left(\mathrm{M}_{0} \mathrm{E}_{0}-\mathrm{M}_{\mathrm{t}} \mathrm{E}_{\mathrm{t}}\right) / \mathrm{M}_{0} \mathrm{E}_{0} \times 100 \%$

$\mathrm{M}_{0}$ is the initial dry weight of straw before decomposition $(\mathrm{g}), \mathrm{M}_{\mathrm{t}}$ is the dry weight of straw (g) when the decomposition time is $t, t$ is the decomposition time (d); $C_{0}$ is the original nutrient content of straw, and $C_{t}$ is the nutrient content of straw when the decomposition time is $t ; E_{0}$ is the original organic component content of straw, and $E_{t}$ is the organic component content of straw when the decomposition time is $t$.

\subsection{Statistical Analysis}

Statistical analyses were carried out using the SPSS (SPSS v17.0) statistical software (SPSS). Relevant data tables and graphs were obtained using Microsoft Excel. 


\section{Results}

\subsection{Decomposition Rate}

The decomposition rate of straw for the different treatments is shown in Figure 2.

During the 240 days of the study, straw decomposition showed a trend of increasing rapidly in the first stages and then increasing slowly in the latter stages in all the treatments. That is, the rapid decomposition period of maize straw was from 0 to $60 \mathrm{~d}$, while the slow decomposition period was from 60 to $150 \mathrm{~d}$, and the stable decomposition period was $150-240 \mathrm{~d}$. The straw decomposition rate of the different treatments varied, following the order $\mathrm{SP}>\mathrm{SC}>\mathrm{SO}>\mathrm{S}$. The fastest straw decomposition was recorded for 0-30 days, and the decomposition rates of SP, SC, and SO were $41.32 \%, 38.81 \%$, and $35.11 \%$, respectively, which were $32.73 \%, 24.67 \%$, and $12.79 \%$, respectively, higher than the $\mathrm{S}$ treatment. Straw decay continued rapidly for 30-60 days, and at $60 \mathrm{~d}$, the straw decomposition rate of SP reached $63.16 \%$. At $240 \mathrm{~d}$, the straw decomposition rates of SP, SC, SO, and S were $71.87 \%$, $69.36 \%, 65.25 \%$, and $52.26 \%$, respectively.

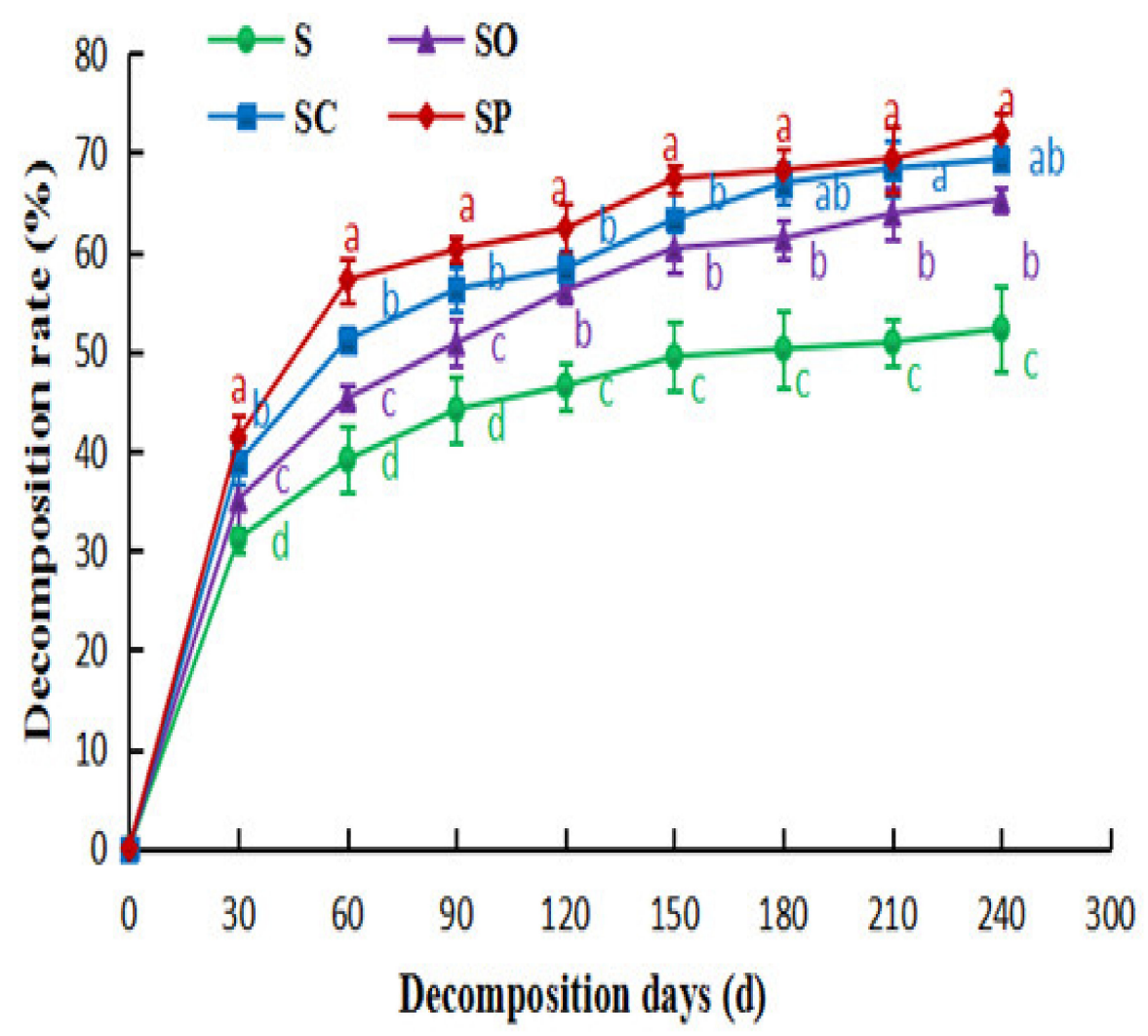

Figure 2. Dynamic changes of the decomposition rate of maize straw ( $\mathrm{S}$, maize straw only; $\mathrm{SO}$, maize straw plus ox manure; SC, maize straw plus chicken manure; SP, maize straw plus pig manure). Note: The different lowercase letters $(\mathrm{a}-\mathrm{d})$ among the different treatments indicate significance at $p<0.05$.

\subsection{Carbon Release Rate}

The carbon release rate of straw for the different treatments is shown in Figure 3. During the process of straw decomposition, the straw continued to release carbon, and with the extension of the decay time, the carbon release was rapid at first (0-90 d), then became slow (90-150 d), and finally tended to be stable (150-240 d). The carbon release rate of treatments with different animal manure was higher than that without manure. At $240 \mathrm{~d}$, the sequence of carbon release rate was SC $(69.35 \%)>$ SP $(67.32 \%)>$ SO $(64.04 \%)>$ S $(57.17 \%)$. 


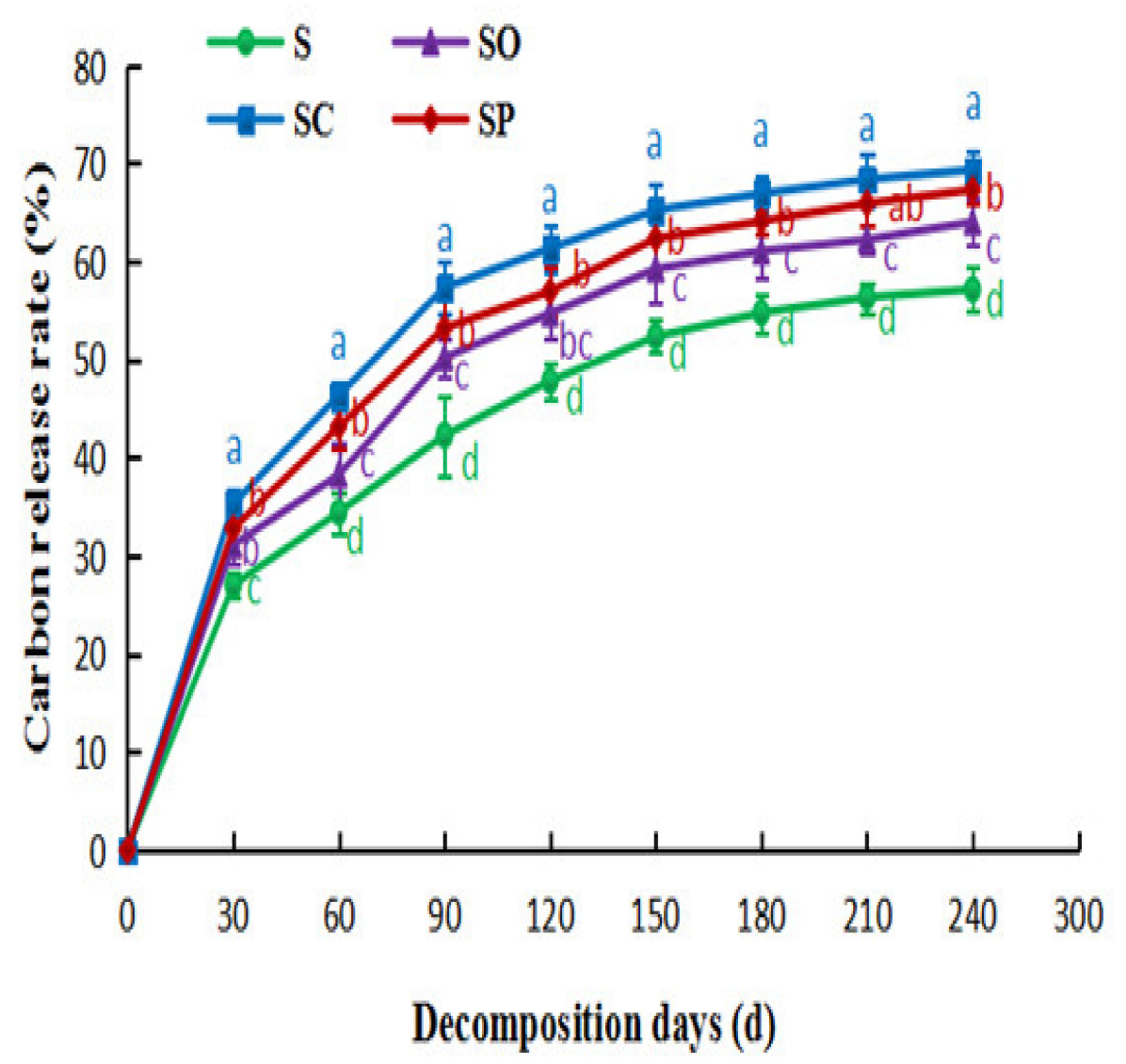

Figure 3. Dynamic changes of the carbon release rate from maize straw ( $\mathrm{S}$, maize straw only; SO, maize straw plus ox manure; SC, maize straw plus chicken manure; SP, maize straw plus pig manure). Note: The different lowercase letters $(a-d)$ among the different treatments indicate significance at $p<0.05$.

\subsection{Nutrient Release Rate of Maize Straw}

The nutrient release rate of straw for the different treatments is shown in Figure 4. During the whole process of straw decomposition, the release rates of nitrogen, phosphorus, and potassium increased gradually, showing a trend of rapid release at first and a slowrelease trend during the latter stages. The release rates of nitrogen, phosphorus, and potassium in the treatments with animal manure were all higher than in the treatment without manure. At $30 \mathrm{~d}$, the nitrogen in maize straw was released rapidly (20.21-27.13\%); the phosphorus release rate from the straws accounted for more than $50 \%$ of the total phosphorus release in the whole test process, and SP treatment had the highest phosphorus release rate $(56.72 \%)$, which was $7.89 \%$ higher than $\mathrm{S}$ treatment $(p<0.05)$; the potassium release rates in SP and SC treatments were $57.34 \%$ and $55.64 \%$, respectively, which were slightly higher than those of the other treatments. At $240 \mathrm{~d}$, the highest nutrient release rate was recorded in SP and SC treatments, and the highest release rate of $\mathrm{P}$ and $\mathrm{K}$ was recorded in SP treatment while the highest release rate of $\mathrm{N}$ was recorded in SC treatment. The higher release rates for $\mathrm{K}$ against the other chemical constituents $(\mathrm{N} \& \mathrm{P})$ are mainly related to the form of nutrient elements in the straw, which determines the release rate of nutrient elements. Potassium and phosphorus mainly exist in ionic form, but phosphorus is especially involved in cell membrane formation, therefore making the release rate of potassium higher than that of phosphorus. Nitrogen, on the other hand, mainly exists in organic form in straw, and its release rate is the slowest. 

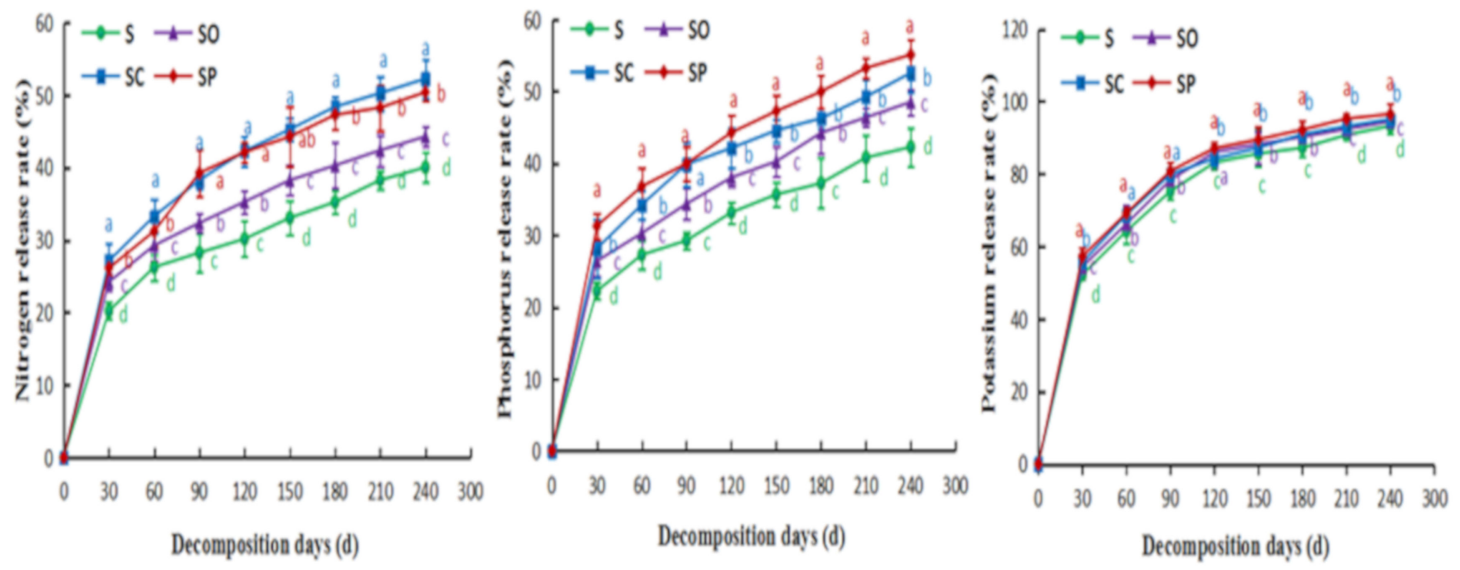

Figure 4. Dynamic changes of the nutrient release rate from maize straw ( $\mathrm{S}$, maize straw only; SO, maize straw plus ox manure; SC, maize straw plus chicken manure; SP, maize straw plus pig manure). Note: The different lowercase letters (a-d) among the different treatments indicate significance at $p<0.05$.

\subsection{Decomposition Rates of Maize Straw Cellulose, Hemicellulose, and Lignin}

The decomposition rate of maize straw cellulose, hemicellulose, and lignin for the different treatments is shown in Figure 5. With the extension of straw degradation time, the decomposition rate of cellulose and hemicellulose treated with different treatments was faster in the early stages $(0-60 \mathrm{~d})$ and slowed down gradually in the latter stage (60-240 d). On the contrary, compared to cellulose and hemicellulose, the decomposition rate of lignin was slow in the early stage (0-30 d) and relatively fast in the latter stage (30-240 d). Compared with lignin, hemicellulose and cellulose begin to be released and decompose faster since they are carbohydrates and are easier to degrade. However, the lignin structure is more complex and contains some components that are difficult to decompose, which increases the difficulty of microbial utilization, thus slowing down its release and decomposition rate. At $240 \mathrm{~d}$, the decomposition rates of cellulose in the different treatments followed the order SO > SP > SC > S, which were $65.47 \%, 64.85 \%, 62.42 \%$, and $54.93 \%$, respectively. At $150 \mathrm{~d}$, the hemicellulose degradation rate of each treatment was more than $80 \%$ of the total decay rate, and at $240 \mathrm{~d}$, the hemicellulose decomposition rates of SO, SP, SC, and S were $60.47 \%, 58.85 \%, 56.57 \%$, and $51.93 \%$, respectively. After 30 days, the decomposition rate of lignin in each treatment was $11.83-18.24 \%$. At the end of the experiment, the degradation rates of lignin followed the order $\mathrm{SP}>\mathrm{SO}>\mathrm{SC}>\mathrm{S}$, which were $54.85 \%, 52.47 \%, 51.57 \%$, and $46.81 \%$, respectively.
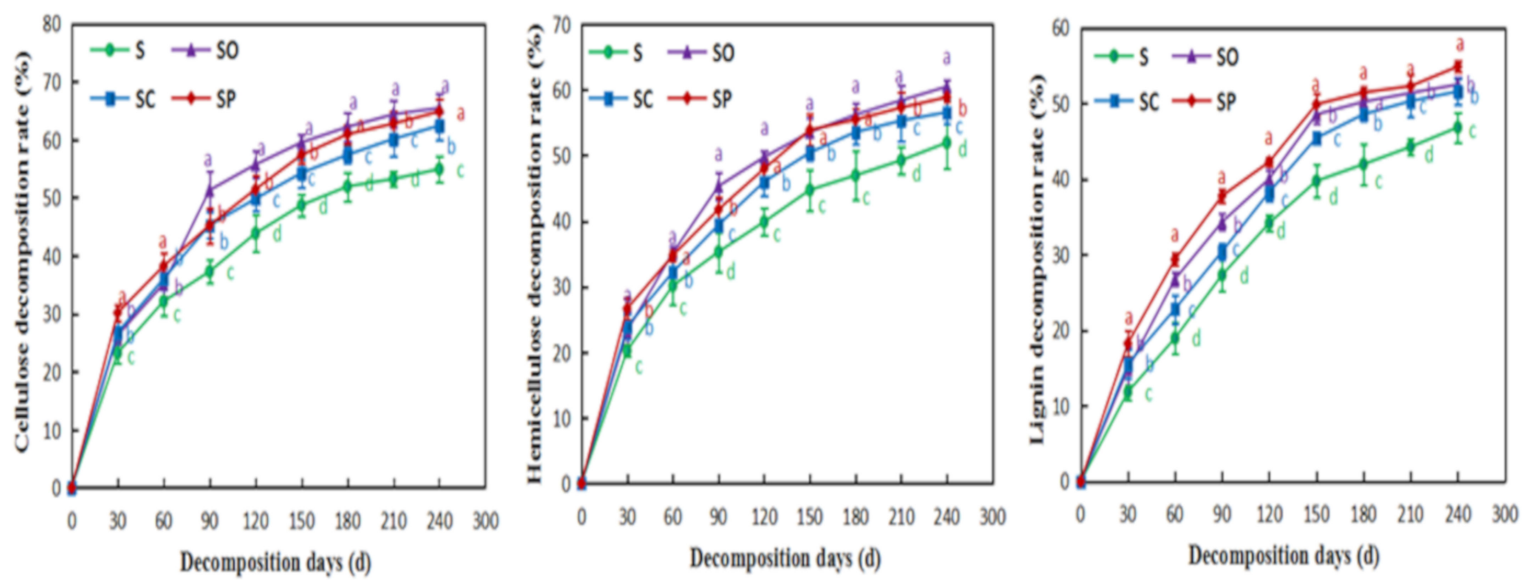

Figure 5. Dynamic changes of cellulose, hemicellulose, and lignin decomposition rate of maize straw (S, maize straw only; $\mathrm{SO}$, maize straw plus ox manure; SC, maize straw plus chicken manure; SP, maize straw plus pig manure). Note: The different lowercase letters $(\mathrm{a}-\mathrm{d})$ among the different treatments indicate significance at $p<0.05$. 


\subsection{SEM Images of Maize Straw Surface Structure}

The decomposition of maize straw at $0,30,90$, and $150 \mathrm{~d}$ was analyzed and compared using scanning electron microscopy (SEM), as shown in Figure 6. The wax layer on the surface of undecomposed maize straw was smooth and dense, without holes, and the fiber bundles were extended and uniform. After 30 days of decomposition, the outer surface of the straw was decomposed, some tissues had fallen off, the regular and flat surface of the straw was destroyed, and the dense structure became loose. At $90 \mathrm{~d}$, cracks appeared on the straw surface, showing uneven holes and faults, and some fiber structures had been destroyed and exposed. At $150 \mathrm{~d}$, the structure of straw was seriously damaged, the large vascular bundles and other structures were decomposed completely, and the remaining tissues were highly lignified and some were difficult to decompose. The degree of damage of the maize straw with animal manure was stronger than that without manure, and the highest decomposition effect on structural changes of straw was observed in SP at all stages of the experiment.
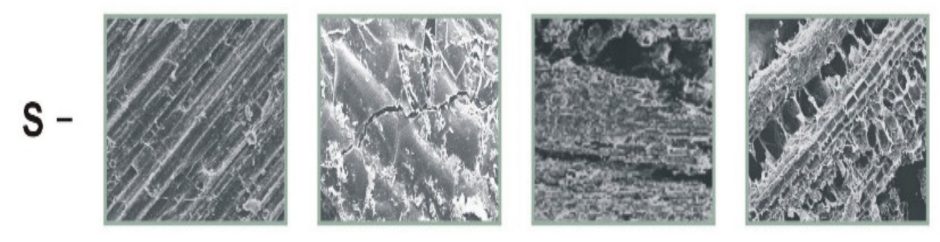

so-
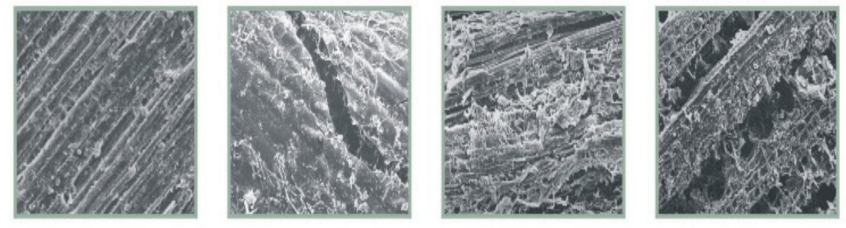

SC-
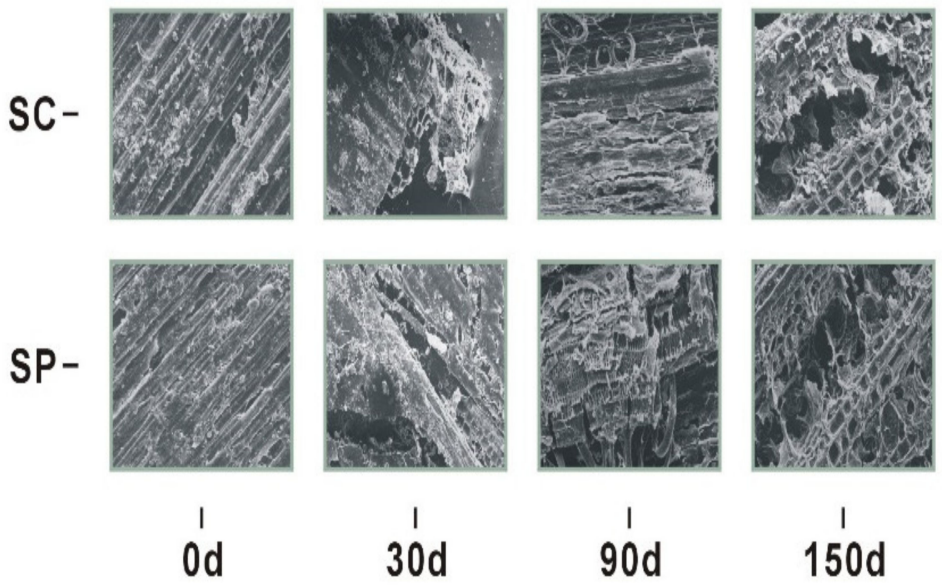

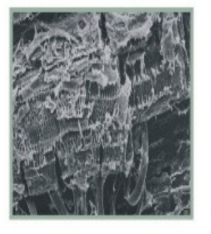

1

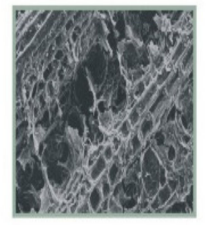

1

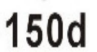

Figure 6. SEM images of maize straw surface structure ( $S$, maize straw only; $S O$, maize straw plus ox manure; SC, maize straw plus chicken manure; SP, maize straw plus pig manure).

\section{Discussion}

Although anaerobic digestion of animal manure or straw biomasses is a wellassessed practice with several reported benefits and advantages in present or previous literature $[18,19]$, some short-term studies have reported that rice straw retention did not increase or have a negative effect on rice yield due to the quality of rice straw $[20,21]$. The main reason is that during the process of straw decomposition, the rice straw amendment cannot reconcile the requirements of nutrients between rice and soil microorganisms (especially the demand for $\mathrm{N}$ ). Decomposition rate and nutrient release are influenced by the biochemical composition and the $\mathrm{C} / \mathrm{N}$ of organic amendments [22,23]. The wide $\mathrm{C} / \mathrm{N}$ of straw may lead to competition for $\mathrm{N}$ between the crop and soil microorganisms. However, mixing high-quality and low-quality organic amendments provides a better strategy to 
match nutrient demands of soil microorganisms and the crop during decomposition of organic amendments $[23,24]$. This changes the quality of organic C entering the soil, which can have a positive impact on soil nutrient availability, microbial activity, and turnover of soil organic matter (SOM) [25,26]. Animal manure usually has high moisture content and high density but a relatively narrow $\mathrm{C} / \mathrm{N}$. Compared with manure, straw has the opposite characteristics (low moisture content, low density, wide $\mathrm{C} / \mathrm{N}$ ); therefore, the combined application of animal manure with straw could be an applicable solution [27].

The rate of straw decomposition is related to its intrinsic conditions and external environment. Therefore, straw with different sizes, $\mathrm{C} / \mathrm{N}$ ratio, composition, and surrounding environment leads to differences in straw decomposition rate [28,29]. In the present study, the decomposition rate of straw showed a trend of increasing rapidly in the first stages and then increasing slowly in the latter stages. This might be attributed to the rapid release of non-structural and easily decomposable substances such as soluble organic matter in the straw in the early stage of decomposition, while in the latter stage, the remaining parts are mainly organic matter that is difficult to decompose, resulting in slow decomposition [30]. In the whole process of decomposition, compared with S, the AM-S treatments significantly increased the decomposition rate of straw, and this was because the straw decomposition process requires the participation of microorganisms. Animal manure contains more carbohydrates, fatty acids, and other nutrients that support the soil microbial life/activities to provide a carbon source, to accelerate the straw decomposition process [31]. The straw decomposition rate of SC and SP treatments in each period was higher than that of other treatments, which might be because the $C / N$ of chicken manure and pig manure was relatively narrow and easily decomposed by microorganisms, thereby creating more conducive conditions to support the growth of microorganisms [32]. In addition, the soluble matter in ox manure was less, while the lignin content and lignin/N ratio were high, making it difficult for it to be used by microorganisms, resulting in a slower straw decomposition rate.

The ratio of carbon to nitrogen is generally expressed as " $\mathrm{C} / \mathrm{N}$ ". It refers to the ratio of the total content of carbon to the total content of nitrogen in organic matter. The proper ratio of carbon to nitrogen improves microbial fermentation. Straw decomposition processes are affected by straw quality and soil microbial community composition; moreover, soil $\mathrm{pH}, \mathrm{C} / \mathrm{N}$ ratio, $\mathrm{N}$ and $\mathrm{P}$ levels, and soil organic carbon (SOC) can affect microbial activities and then affect straw degradation $[33,34]$. Studies have shown that organic materials with a wide $\mathrm{C} / \mathrm{N}$ ratio will decompose faster even when the lignin content of the organic material is small [35]. In this experiment, the lignin contents of chicken manure and pig manure were $3.21 \%$ and $5.09 \%$, respectively, while the $\mathrm{C} / \mathrm{N}$ ratios were 15.14 and 18.27 (Table 1), respectively. Therefore, pig manure was more prone to having a faster decomposition rate and providing sufficient nutrients for the microorganisms to accelerate straw decomposition.

The release of organic carbon from maize straw is controlled by its structure, intrinsic properties, environment (such as climate and soil conditions), and management measures [12]. A previous study reported that the average soil organic carbon (SOC) content significantly increased by $12.8-14.9 \%$ in the $0-15 \mathrm{~cm}$ soil layer after straw returning [36]. In this study, the release of carbon was rapid in the first stage and then slow in the latter stage, which was consistent with Chen's study [37]. The carbon release rate of straws with animal manure was higher than that without animal manure, which may be because different animal manure provided different carbon sources for microorganisms, thus affecting the utilization rate of straws by microorganisms [38]. The carbon release rate of straw added with chicken manure was higher because the $\mathrm{C} / \mathrm{N}$ ratio of chicken manure was relatively narrow, which could easily stimulate soil microbial activity and thus promote the carbon release from straw [39].

Maize straw is rich in nitrogen, phosphorus, potassium, and other nutrients that are released during decomposition [40]. Results from the global meta-analysis also indicated that soil available NPK (nitrogen, phosphorus, and potassium) contents were enhanced by 
$14.1 \%, 10.4 \%$, and $17.8 \%$, respectively, with the incorporation of straw [41]. Wei et al. [42] also indicated that after four years of straw incorporation, the available NPK of soil was improved by $9.1-30.5 \%, 9.8-69.5 \%$, and 10.3-27.3\%, respectively. As such, Yan et al. [43] indicated that the straw returned to the soil serves as a short-term source of $\mathrm{P}$ and $\mathrm{K}$ and a long-term source of $\mathrm{N}$ and $\mathrm{C}$. In this study, the release rates of $\mathrm{N}, \mathrm{P}$, and $\mathrm{K}$ at the end of the experiment were 40.01-52.23\%, 42.25-55.08\%, and 93.25-96.56\%, respectively $(\mathrm{K}>\mathrm{P}>\mathrm{N})$, which was consistent with the study of Dai et al. [44]. The nutrient release rate of straw is affected by its intrinsic chemical properties. The potassium release rate in the straw was the highest, which might be because the content of potassium in the straw was relatively high, and most of the potassium existed in the water-soluble or ionic state, which dissolved easily, thereby increasing the release rate [45]. Usually, part of the phosphorus in the straw constituted the composition of the cell membrane, and the remaining $60 \%$ of the phosphorus in the straw existed in the ionic state. Thus, the phosphorus content was lower than that of potassium; hence, the release rate was slower than that of potassium. Most of the nitrogen in straw exists in the organic state, forming part of the composition of proteins, nucleic acids, chlorophyll, and other organic components in the cell. This increases the degree of cementation, making it difficult to decompose to release the nitrogen [46]. In this study, the release rate of $\mathrm{N}, \mathrm{P}$, and $\mathrm{K}$ was higher in the animal manure treatment than that without, which was consistent with the findings of Guan et al. [10]. The reason for this observation might be because animal manure contained nutrients, providing more substrates for the growth of microorganisms, increasing the abundance of the microbial community, and further accelerating the process of straw decomposition and the release of nutrients.

Lignin, hemicellulose, and cellulose are the important components of maize straw, and their decomposition is mainly affected by the corresponding microorganisms [47]. In this study, the decomposition rates of hemicellulose and cellulose in maize straw were similar to that of straw, indicating that the decomposition of cellulose and hemicellulose affected the decomposition process of straw. The decomposition rate of hemicellulose and cellulose was higher than that of lignin, which indicates that lignin is more difficult to decompose than hemicellulose and cellulose $[48,49]$. Cellulase is a kind of compound enzyme, which can degrade cellulose from straw, and its activity limits the decomposition rate of cellulose [50]. In this study, compared with $S$, straw combined with animal manure promoted the degradation of hemicellulose and cellulose, which might be due to the enhancement of soil cellulase and hemicellulase activities by animal manure. In the later stage, SO recorded the highest decomposition rate, and this was attributed to the fact that the ox is herbivorous, and its manure contained more hemicellulose, cellulose, and other easily decomposable substances that could be used as the selected medium in the soil to cultivate more hemicellulose and cellulose-degrading bacteria, culminating in the production of more corresponding enzymes. In this study, the combined application of animal manure and straw increased the decomposition rate of lignin, which may be due to the fact that animal manure increased the activity of soil microorganisms and enzymes, improved soil void structure, made it lose and ventilated, and improved the degradation degree [51].

Scanning electron microscopy (SEM) can directly reflect the damaging degree and surface structural properties of maize straw during decomposition [52]. Before decomposition, the organizational structure of maize straw was closely and neatly arranged; however, with the extension of decomposition time, the internal structure of maize straw was gradually loosened. The tissue structure of maize straw is mainly comprised of the epidermis, vascular bundle, basic tissue, and the phloem parenchyma cells, which destroy the vascular bundle to decompose the basic tissues. With the extension of sampling time, the surface voids of straw became larger and increased, which was due to the decomposition of cellulose, hemicellulose, and other carbohydrates, and the difficulty of lignin decomposition [53]. In this study, the structural changes in the treatments with the addition 
of animal manure were significantly higher than those without, indicating that the addition of animal manure could promote straw decomposition.

\section{Conclusions}

This study aimed to screen the effective animal fertilizer that can promote straw decomposition and provide a reference for the rational use of straw and animal fertilizer management. In our study, the co-application of animal manure and straw accelerated the decomposition of straw and promoted the release of nutrients and organic components (cellulose, hemicellulose, and lignin). Straw decomposition showed a trend of increasing rapidly at first and then increasing slowly in all treatments. SC and SP had higher carbon release rates and nutrient release rates, while $\mathrm{SO}$ and $\mathrm{SP}$ showed higher organic components release rates than treatments of SC and S. With the prolongation of degradation time, the structure of straw was gradually destroyed, the surface became rough, and the number of cavities increased. The damaging degree of the apparent structure of straw with the addition of animal manure was significantly greater than that without the addition. Moreover, pig manure combined with straw had the highest decomposition rate; therefore, we recommend the $\mathrm{SP}$ treatment as the most effective agronomic practice for enhancing the decomposition of maize straw in agroecosystems.

Author Contributions: Conceptualization, J.W.; methodology, J.W., L.S. and Z.S.; software, Z.S. and J.H.; validation, Z.S.; formal analysis, L.S.; investigation, L.S. and O.-K.Y.; resources, J.W.; data curation, L.S.; writing-original draft preparation, L.S.; writing-review and editing, O.-K.Y.; visualization, J.H.; supervision, J.W.; project administration, J.W.; funding acquisition, J.W. All authors have read and agreed to the published version of the manuscript.

Funding: This research was supported by the Research Foundation of the Science and Technology Agency of Jilin Province, China (20190301018NY), and the National Key Research and Development Program of China (2018YFD0300203, 2017YFD0201801).

Institutional Review Board Statement: Not applicable.

Informed Consent Statement: Not applicable.

Data Availability Statement: Not applicable.

Conflicts of Interest: The authors declare no conflict of interest.

\section{References}

1. Hansen, V.; Müller-Stöver, D.; Imparato, V.; Krogh, P.H.; Jensen, L.S.; Dolmer, A.; Hauggaard-Nielsen, H. The effects of straw or straw-derived gasification biochar applications on soil quality and crop productivity: A farm case study. Environ. Manag. 2017, 186, 88-95. [CrossRef] [PubMed]

2. Li, J.; Wen, Y.; Li, X.; Li, Y.; Yang, X.; Lin, Z.; Song, Z.; Cooper, J.M.; Zhao, B. Soil labile organic carbon fractions and soil organic carbon stocks as affected by long-term organic and mineral fertilization regimes in the North China Plain. Soil Till. Res. 2018, 175, 281-290. [CrossRef]

3. Nan, Q.; Wang, C.; Wang, H.; Yi, Q.; Liang, B.; Xu, J.; Wu, W. Biochar drives microbially-mediated rice production by increasing soil carbon. Hazard. Mater. 2020, 387, 121680. [CrossRef] [PubMed]

4. Eagle, A.J.; Bird, J.A.; Horwath, W.R.; Linquist, B.A.; Brouder, S.M.; Hill, J.E.; Kessel, C. Rice Yield and Nitrogen Utilization Efficiency under Alternative Straw Management Practices. Agron. J. 2000, 92, 1096-1103. [CrossRef]

5. Yanni, S.F.; Whalen, J.K.; Simpson, M.J.; Janzen, H.H. Plant lignin and nitrogen contents control carbon dioxide production and nitrogen mineralization in soils incubated with Bt and non-Bt corn residues. Soil Biol. Biochem. 2011, 43, 63-69. [CrossRef]

6. Zhou, G.P.; Cao, W.D.; Bai, J.S.; Xu, C.X.; Zeng, N.H.; Gao, S.J.; Rees, R.M.; Dou, F.G. Co-incorporation of rice straw and leguminous green manure can increase soil available nitrogen $(\mathrm{N})$ and reduce carbon and $\mathrm{N}$ losses: An incubation study. Pedosphere 2020, 30, 661-670. [CrossRef]

7. Das, M.; Uppal, H.S.; Singh, R.; Beri, S.; Mohan, K.S.; Gupta, V.C.; Adholeya, A. Co-composting of physic nut (Jatropha curcas) deoiled cake with rice straw and different animal dung. Bioresour. Technol. 2011, 102, 6541-6546. [CrossRef] [PubMed]

8. Mary, B.; Recous, S.; Darwis, D.; Robin, D. Interactions between decomposition of plant residues and nitrogen cycling in soil. Plant Soil 1996, 181, 71-82. [CrossRef]

9. Zhang, Z.; Zhang, X.; Xu, M.; Zhang, S.; Huang, S.; Liang, W. Responses of soil micro-food web to long-term fertilization in a wheat maize rotation system. Appl. Soil Ecol. 2016, 98, 56-64. [CrossRef] 
10. Guan, X.K.; Wei, L.; Turner, N.C.; Ma, S.C.; Yang, M.D.; Wang, T.C. Improved straw management practices promote in situ straw decomposition and nutrient release, and increase crop production. J. Clean. Prod. 2020, 250, 119514. [CrossRef]

11. Zhao, S.C.; Qiu, S.J.; Xu, X.P.; Ciampitti, I.A.; Zhang, S.Q.; He, P. Change in straw decomposition rate and soil microbial community composition after straw addition in different long-term fertilization soils. Appl. Soil Ecol. 2019, 138, 123-133. [CrossRef]

12. Latifmanesh, H.; Deng, A.; Li, L.; Chen, Z.; Zhang, W. How incorporation depth of corn straw affects straw decomposition rate and c\&n release in the wheat-corn cropping system. Agric. Ecosyst. Environ. 2020, 300, 107000.

13. Wang, F.T.; Zhang, X.; Yue, X.Y.; Song, M.Y.; Zhang, G.S.; Ming, J. Black Carbon: The Concentration and Sources Study at the Nam Co Lake, the Tibetan Plateau from 2015 to 2016. Atmosphere 2020, 11, 624. [CrossRef]

14. Fan, J.; Xiao, J.; Liu, D.; Ye, G.; Luo, J.; Houlbrooke, D.; Laurenson, S.; Yan, J.; Chen, L.; Tian, J.; et al. Effect of application of dairy manure, effluent and inorganic fertilizer on nitrogen leaching in clayey fluvo-aquic soil: A lysimeter study. Sci. Total Environ. 2017, 592, 206-214. [CrossRef] [PubMed]

15. Chung, C.E.; Kim, S.W.; Lee, M.; Yoon, S.C.; Lee, S. Carbonaceous aerosol AAE inferred from in-situ aerosol measurements at the Gosan ABC super site, and the implications for brown carbon aerosol. Atmos. Chem. Phys. 2012, 12, 6173-6184. [CrossRef]

16. Walkley, A.; Black, L.A. An examination of the Degtjareff method of determining soil organic matter, and a proposed modification of the chromic acid titration method. Soil Sci. 1934, 37, 29-38. [CrossRef]

17. Van-Soest, P.J. Use of detergents in the analysis of fibrous feeds II. A rapid method for the determination of fiber and lignin. Assoc. Off. Agr. Chem. Jour. 1963, 46, 829-835.

18. Wang, F.; Pei, M.F.; Qiu, L.; Yao, Y.Q.; Zhang, C.G.; Qiang, H. Performance of Anaerobic Digestion of Chicken Manure Under Gradually Elevated Organic Loading Rates. Int. J. Environ. Res. Public Health 2019, 16, 2239. [CrossRef]

19. Ferraro, A.; Massini, G.; Miritana, V.M.; Signorini, A.; Race, M.; Fabbricino, M. A simplified model to simulate bioaugmented anaerobic digestion of lignocellulosic biomass: Biogas production efficiency related to microbiological data. Sci. Total. Environ. 2019, 691, 885-895. [CrossRef]

20. Huang, S.; Zeng, Y.; Wu, J.; Shi, Q.; Pan, X. Effect of crop residue retention on rice yield in China: A meta-analysis. Field Crop. Res. 2013, 154, 188-194. [CrossRef]

21. Liao, P.; Huang, S.; van Gestel, N.C.; Zeng, Y.; Wu, Z.; van Groenigen, K.J. Liming and straw retention interact to increase nitrogen uptake and grain yield in a double rice-cropping system. Field Crop. Res. 2018, 216, 217-224. [CrossRef]

22. Kumar, K.A.; Swain, D.K.; Bhadoria, P.B.S. Split application of organic nutrient improved productivity, nutritional quality and economics of rice-chickpea cropping system in lateritic soil. Field Crop. Res. 2018, 223, 125-136. [CrossRef]

23. Marschner, P.; Hatam, Z.; Cavagnaro, T.R. Soil respiration, microbial biomass and nutrient availability after the second amendment are influenced by legacy effects of prior residue addition. Soil Biol. Biochem. 2015, 88, 169-177. [CrossRef]

24. Kaewpradit, W.; Toomsan, B.; Cadisch, G.; Vityakon, P.; Limpinuntana, V.; Saenjan, P.; Jogloy, S.; Patanothai, A. Mixing groundnut residues and rice straw to improve rice yield and $\mathrm{N}$ use efficiency. Field Crop. Res. 2009, 110, 130-138. [CrossRef]

25. Nair, A.; Ngouajio, M. Soil microbial biomass, functional microbial diversity, and nematode community structure as affected by cover crops and compost in an organic vegetable production system. Appl. Soil Ecol. 2012, 58, 45-55. [CrossRef]

26. Sharma, P.; Laor, Y.; Raviv, M.; Medina, S.; Saadi, I.; Krasnovsky, A.; Vager, M.; Levy, G.J.; Bar-Tal, A.; Borisover, M. Green manure as part of organic management cycle: Effects on changes in organic matter characteristics across the soil profile. Geoderma 2017, 305, 197-207. [CrossRef]

27. Qian, X.; Shen, G.; Wang, Z.; Guo, C.; Liu, Y.; Lei, Z.; Zhang, Z. Co-composting of livestock manure with rice straw: Characterization and establishment of maturity evaluation system. Waste Manag. 2014, 34, 530-535. [CrossRef]

28. Baumann, K.; Marschner, P.; Smernik, R.J. Residue chemistry and microbial community structure during decomposition of eucalypt, wheat and vetch residues. Soil Biol. Biochem. 2009, 41, 1966-1975. [CrossRef]

29. Preston, C.M.; Bhatti, J.S.; Flanagan, L.B. Stocks, chemistry, and sensitivity to climate change of dead organic matter along the Canadian boreal forest transect case study. Clim. Chang. 2006, 74, 223-251. [CrossRef]

30. Yue, D.; Cai, L.Q.; Qi, P.; Zhang, R.Z.; Wu, J.; Gao, X.L. The decomposition characteristics and nutrient release of wheat and corn straw under different returning amount. J. Arid. Land Resour. Environ. 2016, 30, 80-85.

31. Shen, F. Study on key technologies of biodegradation and anaerobic digestion of rice straw and pig manure. Jiangxi Agric. Univ. 2019, 12, 703-713.

32. Zhang, W.M.; Yu, C.X.; Wang, X.J.; Hai, L. Increased abundance of nitrogen transforming bacteria by higher C/N ratio reduces the total losses of $\mathrm{N}$ and $\mathrm{C}$ in chicken manure and corn stover mix composting. Bioresour. Technol. 2020, 297, 122410. [CrossRef]

33. Henriksen, T.M.; Breland, T.A. Carbon mineralization, fungal and bacterial growth, and enzyme activities as affected by contact between crop residues and soil. Biol. Fertil. Soils. 2002, 35, 41-48. [CrossRef]

34. Geisseler, D.; Horwath, W.R.; Scow, K.M. Soil moisture and plant residue addition interact in their effect on extracellular enzyme activity. Pedobiologia 2011, 54, 71-78. [CrossRef]

35. $\mathrm{Hu}, \mathrm{J}$. Decomposition characteristics of organic materials in semi-arid soil under plastic film mulching drip irrigation and its effect on organic carbon. Jilin Agric. Univ. 2018, 200, 313-321.

36. Liu, C.; Lu, M.; Cui, J.; Li, B.; Fang, C. Effects of straw carbon input on carbon dynamics in agricultural soils: A meta-analysis. Glob. Chang. Biol. 2014, 20, 1366-1381. [CrossRef]

37. Chen, X.F.; Liu, M.; Kuzyakov, Y.; Li, W.T.; Liu, J.; Jiang, C.Y.; Wu, M.; Li, Z.P. Incorporation of rice straw carbon into dissolved organic matter and microbial biomass along a 100-year paddy soil chronosequence. Appl. Soil Ecol. 2018, 130, 84-90. [CrossRef] 
38. Kamble, P.N.; Bååth, E. Comparison of fungal and bacterial growth after alleviating induced N-limitation in soil. Soil Biol. Biochem. 2016, 103, 97-105. [CrossRef]

39. Qi, Y.F.; Tian, X.M.; Wei, M.; Wang, X.F. Effects of Crop Residues and Application Manners on Properties of Continuous Cropping Cucumber Soil in Solar Greenhouses. Hortic. Environ. Biotechnol. 2009, 50, 410-415.

40. Yan, F.J.; Sun, Y.J.; Hui, X.; Jiang, M.J.; Xiang, K.H.; Wu, Y.X.; Zhang, Q.; Tang, Y.; Yang, Z.Y.; Sun, Y.Y.; et al. The effect of straw mulch on nitrogen, phosphorus and potassium uptake and use in hybrid rice. Paddy Water Environ. 2019, 17, 23-33. [CrossRef]

41. Xia, L.; Lam, S.K.; Wolf, B.; Kiese, R.; Chen, D.; Butterbach-Bahl, K. Trade-offs between soil carbon sequestration and reactive nitrogen losses under straw return in global agroecosystems. Glob. Chang. Biol. 2018, 24, 5919-5932. [CrossRef]

42. Wei, T.; Zhang, P.; Wang, K.; Ding, R.; Yang, B.; Nie, J.; Jia, Z.; Han, Q. Effects of wheat straw incorporation on the availability of soil nutrients and enzyme activities in semiarid areas. PLoS ONE 2015, 10, e0120994. [CrossRef]

43. Yan, C.; Yan, S.S.; Jia, T.Y.; Dong, S.K.; Gong, Z.P. Decomposition characteristics of rice straw returned to the soil in northeast China. Nutr. Cycl. Agroecosyst. 2019, 114, 211-224. [CrossRef]

44. Dai, Z.G.; Lu, J.W.; Li, X.K.; Lu, M.X.; Yang, W.B.; Gao, X.Z. Nutrient release characteristics of straw returned from different crops Trans. CSAE 2010, 26, 272-276.

45. Wu, J.; Guo, X.; Wang, Y.; Xu, Z.; Lu, J. Decomposition Characteristics of Rapeseed and Wheat Straws Under Different Rice Cultivations and Straw Mulching Models. Sci. Agric. Sin. 2011, 44, 3351-3360.

46. Devêvre, O.C.; Horwáth, W.R. Decomposition of rice straw and microbial carbon use efficiency under different soil temperatures and moistures. Soil Biol. Biochem. 2000, 32, 1773-1785. [CrossRef]

47. Deng, Y.Y.; Huang, Z.X.; Ruan, W.Q.; Zhao, M.X.; Miao, H.F.; Ren, H.Y. Co-inoculation of cellulolytic rumen bacteria with methanogenic sludge to enhance methanogenesis of rice straw. Int. Biodeterior. Biodegrad. 2017, 117, 224-235. [CrossRef]

48. Zhou, C.; Liu, Z.; Huang, Z.L.; Dong, M.; Yu, X.L.; Ning, P. A new strategy for co-composting dairy manure with rice straw: Addition of different inocula at three stages of composting. Waste Manag. 2015, 40, 38-43. [CrossRef] [PubMed]

49. Kuijk, S.J.A.; Sonnenberg, A.S.M.; Baars, J.J.P.; Hendriks, W.H.; Cone, J.W. The effect of adding urea, manganese and linoleic acid to wheat straw and wood chips on lignin degradation by fungi and subsequent in vitro rumen degradation. Anim. Feed. Sci. Technol. 2016, 213, 22-28. [CrossRef]

50. Ilmen, M.; Saloheimo, A.; Onnela, M.; Penttila, M.E. Regulation of cellulase gene expression in the filamentous fungus Trichoderma reesei. Appl. Environ. Microbiol. J. 2007, 63, 1298-1306. [CrossRef]

51. Wang, Z.J.; Wang, Z.Y.; Zhang, Z.; Lin, G.Y.; Liu, Z.; Cui, F. Effects of biochar on decomposition characteristics of straw returning with mixed application of bog fertilizer. Trans. Chin. Soc. Agric. Mach. 2018, 49, 279-285.

52. Li, Y.H.; Bai, Y.X.; Pan, C.M.; Li, W.W.; Zheng, H.Q.; Zhang, J.N.; Fan, Y.T.; Hou, H.W. Effective conversion of maize straw wastes into bio-hydrogen by two-stage process integrating $\mathrm{H}_{2}$ fermentation and MECs. Environ. Sci. Pollut. Res. 2015, 22, 18394-18403. [CrossRef] [PubMed]

53. Zeng, L.; Zhang, X.; Zhang, S.Q.; Wang, X.B.; Liang, G.Q.; Zhou, W.; Ai, C.; Zhang, Y.Q. Effects of nitrogen application rates on the decomposition of wheat straw and its nutrient release and structure in fluvial soil. Plant Nutr. Fertil. Sci. 2020, 26, 1565-1577. 